\title{
Kierunki rozwoju aglomeracji poznańskiej - uwagi na marginesie dotychczasowej współpracy i propozycji przylączania ościennych gmin do miasta Poznania
}

\begin{abstract}
Streszczenie: Motywy działań integracyjnych gmin na wielu płaszczyznach nie ulegają zmianie. W kontekście aglomeracyjnych wyzwań miasta Poznania i ościennych gmin, wskazać można zbiór wspólnych interesów mieszkańców, który ze względu na występujące powiązania funkcjonalne powinien być objęty nową, integracyjną formą zarządzania i koordynacji. Źle rozumiana konkurencja może wykluczać poszczególne gminy i marginalizować ich znaczenie w skali regionu i kraju. W jej efekcie dotychczasowe korzyści płynące ze współpracy stracą na swym znaczeniu, co może przełożyć się na fragmentację polityki aglomeracji poznańskiej. Projekt metropolitalny Poznania diagnozuje potrzeby aglomeracji poznańskiej, wskazuje na kierunki działań na płaszczyźnie zbiorowego transportu publicznego, gospodarki przestrzennej, bezpieczeństwa i współpracy sektorowej. Nie zakłada jednak łączenia administracyjnego gmin, lecz opiera się na założeniach metroplitan governance. Wskazuje i wykorzystuje model integracji na gruncie wspólnoty celów strategicznych możliwych do realizacji w ramach określonych przez ustawodawstwo krajowe i europejskie modeli współpracy samorządów. Dzięki nowym mechanizmom dystrybucji środków unijnych w ramach polityki regionalnej - Zintegrowanym Inwestycjom Terytorialnym - Poznań i powiat poznański zyskują argument na rzecz zacieśnienia współpracy. Efektem integracyjnego spill over może być nowy model metropolitalnego zarządzania. Nowy rodzaj ponadgminnej, aglomeracyjnej współpracy wymaga działań politycznych, często jednomyślności, zawiązywania koalicji wokół określonych rozwiązań, lub też budowania pakietów decyzyjnych tylko w części satysfakcjonujących każdego z ich autorów.
\end{abstract}

Słowa kluczowe: aglomeracja, Poznań, integracja, zarządzanie metropolią

Tierunki rozwoju miasta Poznania i aglomeracji poznańskiej sa poMchodną zmian zachodzących na poziomie regionu i kraju. Wpisują się w europejskie standardy polityki miejskiej, której zasady i cele określone zostały w programach polityki regionalnej i innych dokumentach strategicznych Unii Europejskiej. Cele rozwojowe polityki aglomeracji 
poznańskiej kreśli zbiór czynników o charakterze endogennym i egzogennym. Wśród nich można wskazać na zmieniający się potencjał miasta Poznania i jego pozycję konkurencyjną z innymi podobnymi krajowymi i zagranicznymi miastami. Ponadto ulegającą ciagłej zmianie strukturę przestrzenną miasta Poznania i otaczających gmin; proces metropolizacji - rozumianej jako nabywanie określonych funkcji metropolitalnych przez Miasto Poznań. Wskazać należy na większą ruchliwość przestrzenną zarówno poznaniaków, jak i osób dojeżdżających do pracy z odleglejszych części Wielkopolski, na fragmentację przestrzeni i pustoszenie centrum, czy też na silną presję migracyjną do miejscowości bezpośrednio sąsiadujących z Poznaniem. Nie bez znaczenia pozostają dotychczasowe działania integracyjne; deindustrializacja miasta i nastawienie się na świadczenie różnego rodzaju usług, wzrost zamożności części mieszkańców, rozdzielenie miejsc zamieszkania, pracy i korzystania z usług wpływające z kolei na większą mobilność mieszkańców w ramach całego obszaru aglomeracyjnego. Nie sposób nie dostrzec zmian w strukturze demograficznej Poznania, identyfikacji miasta Poznania w oczach jego mieszkańców i osób tu zamieszkujących. Analiza tych zmiennych pozwala sądzić, że zarówno Poznań, jak aglomeracja poznańska podlegają procesowi transformacji funkcjonalnej, przestrzennej, instytucjonalnej i obywatelskiej.

Cele Krajowej Polityki Miejskiej ${ }^{1}$ zakładają intensyfikację działań integracyjnych na wielu szczeblach, zwłaszcza w takich dziedzinach jak terytorium, funkcjonalność, planowanie przestrzenne, instytucje, transport. Zwraca się uwagę na konieczność wypracowania nowej formuły zarządzania zmieniającą się przestrzenią publiczną. Mieszkańcy aglomeracji nie definiują bowiem granic administracyjnych dzielących ich gminy. Nie postrzegają ich w kategoriach barier rozwojowych. Zaspokajają swoje życiowe potrzeby w różnych miejscach, różnych gminach. W centrum aglomeracji, w dużym mieście znajdują miejsca kształcenia się, pracy, ciekawej oferty kulturalnej czy też opieki zdrowotnej na oczekiwanym poziomie. W podmiejskich terenach znajdują przestrzeń mieszkaniową, miejsce relaksu, zaspokojenia potrzeb innego rodzaju. Tereny te są bardziej dostępne dla potencjalnych inwestorów, którzy tworzą miejsca pracy i wpływają na kierunki migracji zarobkowej. Na podstawie takiego doświadczenia przestrzeni rodzi się nowy rodzaj oczekiwań społecznych związanych z zapewnieniem określonego poziomu usług publicznych

\footnotetext{
1 Szczegółowe cele zobacz w: Krajowa Polityka Miejska.
} 
o charakterze aglomeracyjnym. Ich realizacja będzie połączeniem dotychczasowych zadań gmin ze sprawnym zarządzaniem aglomeracyjnym, międzygminnym. Będzie musiała sprostać potrzebom mieszkańca nowego typu, który swoim potencjałem definiuje kapitał aglomeracji pozwalający jej na konkurowanie z pozostałymi regionami w skali kraju i Europy. Kształtujące się formy zarządzania metropolitalnego muszą objąć swoim zasięgiem następujące grupy zadań:

1. „Zaspokojenie zbiorowych potrzeb mieszkańców, w ramach których realizowane są takie zadania jak transport publiczny, porządek i bezpieczeństwo publiczne, służba zdrowia, kultura, edukacja;

2. planowanie strategiczne realizowane za pomocą wspólnej strategii obszaru metropolitalnego, zarządzanie drogami publicznymi, planowanie przestrzenne, strategia promocji;

3. ochrona środowiska związana z zadaniami dotyczącymi gospodarki wodno-ściekowej, polityka proekologiczna, rekultywacja terenów zdegradowanych" (Zielona Księga, 2012, s. 11).

Powstała na skutek większej mobilności społecznej nowa definicja przestrzeni bywa badana $\mathrm{z}$ wielu perspektyw. W efekcie tych prac wykształcono nową siatkę pojęć. Aczkolwiek przyznać trzeba, że w dziedzinie badań nad metropoliami, nad obszarami aglomeracyjnymi dostrzec można pewien eklektyzm pojęciowy.

W większych skupiskach ludzi zamieszkujących określone terytorium, o doświadczeniach aglomeracyjnych mówimy o powstaniu metropolii lub ośrodków aglomeracyjnych. Ze względu na to, że polskie, duże ośrodki miejskie nie spełniają przyjętych kryteriów metropolitalnych, a i nie wszystkie z nich wykształciły już cechy aglomeracyjne, w polskich dokumentach strategicznego rozwoju kraju, określa się je mianem Miejskich Obszarów Funkcjonalnych (KPZK, 2012, s. 81). Koncepcja Przestrzennego Zagospodarowania Kraju definiuje jako obszar kraju wyodrębniony na podstawie wspólnych cech geograficznych i silnych wewnętrznych powiązań. Przykładem obszaru funkcjonalnego może być duże miasto i otaczające je gminy. Mieszkańcy tych gmin na co dzień dojeżdżają do pracy w mieście, uczą się w nim, studiują chodzą do teatru. Oznacza to, że taki obszar posiada wspólny potencjał i bariery rozwojowe, niezależne od granic administracyjnych. Planowanie przestrzenne czy szerzej - planowanie rozwoju - ponad tymi granicami, pozwala osiagnąć lepsze efekty (KPZK, 2012, s. 81).

Obszary te wymagają wspólnego zarządu i szerszej perspektywy koordynacyjnej. W odpowiedzi na to zapotrzebowanie ustawodawca 
przewiduje formy ponadlokalnej współpracy samorządów. Do tych najważniejszych zaliczyć należy: porozumienia międzygminne, związki międzygminne, tzw. centra wspólnych usług, związki metropolitalne, stowarzyszenia samorządowe, celowe spółki komunalne i in.

Celem niniejszego opracowania jest udzielenie odpowiedzi na następujące pytania badawcze:

1. Jakie modele ponadgminnego zarządzania i koordynacji pozwalają już dzisiaj na integrację zadań gmin aglomeracji poznańskiej i w jakich dziedzinach?

2. Jakie są różnice między poszczególnymi modelami integracji?

3. Jakie zadania gminne są aktualnie objęte formami współpracy międzygminnej na obszarze Miejskiego Obszaru Funkcjonalnego Miasta Poznania?

4. Jaki model rozwoju można wskazać jako docelowy dla aglomeracji poznańskiej?

Autor stawia następujące tezy:

1. Motywy działań integracyjnych gmin na wielu płaszczyznach nie ulegają zmianie. W kontekście aglomeracyjnych wyzwań miasta Poznania i ościennych gmin, wskazać można zbiór wspólnych interesów mieszkańców, który ze względu na występujące powiązania funkcjonalne powinien być objęty nową, integracyjną formą zarządzania i koordynacji. Źle rozumiana konkurencja może wykluczać poszczególne gminy i marginalizować ich znaczenie w skali regionu i kraju. W jej efekcie dotychczasowe korzyści płynące ze współpracy stracą na swym znaczeniu, co może przełożyć się na fragmentację polityki aglomeracji poznańskiej.

2. Dotychczasowe działania integracyjne na terenie aglomeracji poznańskiej zaliczyć można do kategorii soft politics. Nie umniejsza to bynajmniej ich znaczenia. Diagnoza i wypracowanie dokumentów strategicznych jak Biała Księga Aglomeracji Poznańskiej, Koncepcja Przestrzennego Zagospodarowania Metropolii Poznań i in., są kamieniami milowymi w myśleniu o przyszłości miasta Poznania i gmin aglomeracji poznańskiej.

3. Projekt metropolitalny diagnozuje potrzeby aglomeracji poznańskiej, wskazuje na kierunki działań na płaszczyźnie zbiorowego transportu publicznego, gospodarki przestrzennej, bezpieczeństwa i współpracy sektorowej. Nie zakłada jednak łączenia administracyjnego gmin, lecz opiera się na założeniach metropolitan governance. Wskazuje i wykorzystuje model integracji na gruncie wspólnoty celów strategicznych 
możliwych do realizacji w ramach określonych przez ustawodawstwo krajowe i europejskie modeli współpracy samorządów.

4. Dzięki nowym mechanizmom dystrybucji środków unijnych w ramach polityki regionalnej - Zintegrowanym Inwestycjom Terytorialnym - Poznań i powiat poznański zyskują argument na rzecz zacieśnienia współpracy. Efektem integracyjnego spill over może być nowy model metropolitalnego zarządzania. Sam mechanizm ZIT zarówno po stronie planowania wydatków, jak i ich realizacji daje aglomeracji poznańskiej możliwość wkroczenia na nowy etap integracji. Przy dość dużych różnicach rozwojowych między poszczególnymi gminami trudno przesądzać, w którym kierunku będą zmierzały decyzje polityków. Nowy rodzaj ponadgminnej, aglomeracyjnej współpracy wymaga bowiem działań politycznych, często jednomyślności, zawiązywania koalicji wokół określonych rozwiązań, lub też budowania pakietów decyzyjnych tylko w części satysfakcjonujących każdego z ich autorów.

\section{Współpraca międzygminna jako przykład integracji i ponadgminnego zarządzania i koordynacji}

W przestrzeni aglomeracyjnej mogą się rozwinąc funkcje metropolitalne. W przypadku gdy jądrem aglomeracji jest miasto - metropolia, o obszarze tym mówimy metropolitalny. Zgodnie z przyjętą w Koncepcji Przestrzennego Zagospodarowania Kraju definicją obszaru metropolitalnego za taki uważa się obszar wielkiego miasta oraz powiązanego z nim funkcjonalnie otoczenia (KPZK, 2012, s. 187). Należy mieć na względzie, że rozwój przestrzenny i demograficzny aglomeracji nie jest warunkiem wystarczającym do przekształcenia jej w obszar metropolitalny. Podstawową cechą aglomeracji jest powiązanie obszarów zurbanizowanych, a obszaru metropolitalnego jest integracja funkcjonalna i zewnętrzne funkcje metropolitalne. Według typologii przyjętej w KPZK w ramach miejskich obszarów funkcjonalnych wyznacza się ośrodki wojewódzkie w tym obszary metropolitalne. Ponadto w ramach miejskich obszarów funkcjonalnych wskazano na ośrodki regionalne, subregionalne i ośrodki krajowe. Administracyjnie obszary te mogą obejmować gminy miejskie, gminy wiejskie i miejsko-wiejskie.

W oparciu o kryteria definiujące ośrodki metropolitalne proponuje się definicję obszaru metropolitalnego jako tego, który obejmuje stre- 
fę o znacznym bezpośrednim zasięgu codziennego oddziaływania wraz z terenami potencjalnych możliwości rozwojowych, w którym zachodzą procesy metropolizacji i występuje wystarczające nagromadzenie działalności uzupełniających. To obszar o dużej skali wewnętrznej integracji funkcjonalnej z dobrze rozwiniętą siecią transportową (por. KPZK, 2012, s 188 i n.).

Kierując się powyższymi wytycznymi uznać należy, że miasto Poznań ze względu na swe położenie, znaczenie regionalne i ponadregionalne, liczbę ludności, akademickie tradycje, lokalizację portu lotniczego i pozostałe kryteria jest miastem wiodącym w obszarze funkcjonalnym ukształtowanym wraz z gminami powiatu poznańskiego.

Potencjał integracyjny aglomeracji poznańskiej jest znaczący. Przyjęta w 2011 roku Strategia Rozwoju Aglomeracji Poznańskiej definiuje te najważniejsze cechy, wśród nich:

1) skupienie podmiejskich miast i gmin w granicach administracyjnych jednego, dużego powiatu ziemskiego;

2) wyjątkowo silne natężenie procesu suburbanizacji;

3) dynamiczny rozwój przestrzenny, którego wynikiem są duże zmiany środowiskowe i infrastrukturalne. Intensyfikacja ruchu komunikacyjnego i wzrost mobilności ludności w ramach urbanizującego się obszaru;

4) wysoki poziom rozwoju gospodarczego, mierzony wartością PKB, wysokim poziomem przedsiębiorczości oraz licznymi inwestycjami z udziałem kapitału zagranicznego, zarówno w Poznaniu, jak i w sąsiednich gminach;

5) bardzo dobrze rozwinięte funkcje akademickie, najwyższy wśród dużych miast kraju udział studentów w populacji miasta, wysoki poziom internacjonalizacji badań i kształcenia;

6) innowacyjne pomysły w zakresie zarządzania, organizacji transportu miejskiego, świadczenia usług społecznych i realizacji zadań z zakresu gospodarki komunalnej;

7) wysoki poziom życia, wyrażający się najwyższym po Warszawie stopniem motoryzacji, wysokim poziomem zamożności, dobrym dostępem do usług i zadowoleniem z życia mieszkańców" (Strategia Rozwoju Aglomeracji Poznańskiej, 2011, s. 28).

Potencjał integracyjny aglomeracji uzupełniają dane statystyczne ${ }^{2}$ określające:

\footnotetext{
${ }^{2}$ Na podstawie: Statystyczne Vademecum Samorzqdowca 2015.
} 
a) powierzchnię aglomeracji - $3082 \mathrm{~km}^{2-}$ co stanowi 10,3\% powierzchni województwa;

b) ludność: 1018557 mieszkańców, co stanowi 29,3\% ludności województwa;

c) gęstość zaludnienia: 330 osób na 1 km²;

d) przyrost naturalny: $2,1 \%$;

e) saldo migracji na 1000 ludności: 3,1\%;

f) liczbę podmiotów w rejestrze REGON na 10 tys. ludności w wieku produkcyjnym: 2 726,3;

g) średnie dochody budżetowe JST na 1 mieszkańca: 4 357,1 zł - wyższe niż średnia dla województwa;

h) średnie wydatki budżetowe JST na 1 mieszkańca 4 102,6 zł - wyższe niż średnia dla województwa;

i) stopę bezrobocia: 3,0\% - średnia dla województwa to 5,3\%;

j) liczbę oddanych do użytku mieszkań: 7 461, co stanowi 51\% oddanych mieszkań w województwie wielkopolskim.

Ponadto wskazać można, iż atutem metropolii w budowaniu swej pozycji konkurencyjnej są dobrze funkcjonujące instytucje publiczne. „Jakość przywództwa politycznego, kompetencje rady miasta, zdolności menedżerskie prezydenta, fachowość, kreatywność wyższych urzędników, organizacja i standardy pracy kadry administracyjnej mają duże znaczenie dla poziomu życia mieszkańców. [...] Elementowi zarządzania i administracji odpowiadają dwa kapitały: kapitał instytucjonalno-demokratyczny oraz kapitał źródeł finansowania" (Mikuła, 2012, s. 201).

$\mathrm{Na}$ analizowanym obszarze rozwinęły się znane w Polsce formy ponadgminnej współpracy. Wśród nich: porozumienia międzygminne, związki międzygminne, stowarzyszenia gmin i powiatów. Z powodzeniem działają spółki komunalne świadczące usługi również dla gmin sąsiadujących z miastem Poznaniem. Zaś gminy należące do stowarzyszenia Metropolia Poznań zyskały nowy instrument integracyjny, jakim jest budżet Zintegrowanych Inwestycji Terytorialnych. Dla wzmocnienia zarządzania aglomeracyjnego ustawodawca wypracował i przyjął nowelizację ustawy o samorządzie gminnym i nową ustawę o związkach metropolitalnych. Ta pierwsza ustawa przewiduje dwie nowe formuły koordynacji i zarządzania: związki gminno-powiatowe oraz wspólną obsługę administracyjną i finansową w postaci centrum usług wspólnych. Nowe możliwości otwierają się przed gminami, które dla wsparcia swej dotychczasowej współpracy potrzebują nowej instytucji: związku metro- 
politalnego, który od dnia 1 stycznia 2016 może zostać ustanowiony po spełnieniu ustawowych warunków.

Wybrane przykłady dotychczasowej międzygminnej współpracy w MOF Poznania w wybranych dziedzinach wskazuje tabela 1.

Tabela 1

Wybrane przykłady integrujące gminy aglomeracji poznańskiej

\begin{tabular}{|c|c|c|}
\hline $\begin{array}{c}\text { Nazwa } \\
\text { podmiotu }\end{array}$ & $\begin{array}{c}\text { Forma orga- } \\
\text { nizacyjna }\end{array}$ & Przedmiot działalności (wybrane) \\
\hline 1 & 2 & 3 \\
\hline $\begin{array}{l}\text { Poznańska Lokal- } \\
\text { na Organizacja } \\
\text { Turystyczna }\end{array}$ & $\begin{array}{l}\text { Stowarzysze- } \\
\text { nie }\end{array}$ & 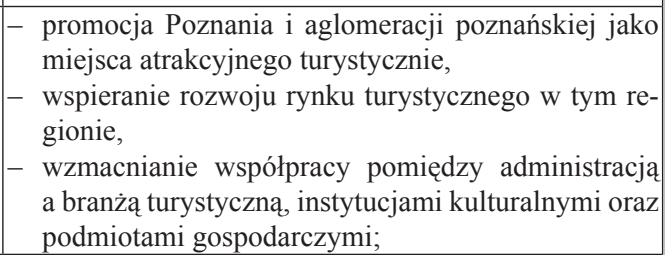 \\
\hline \begin{tabular}{|lr} 
Zarząd & Trans- \\
portu & Miejskiego \\
- jednostka & orga- \\
nizacyjna & miasta \\
Poznania & \\
\end{tabular} & $\begin{array}{l}\text { Porozumienie } \\
\text { międzygmin- } \\
\text { ne }\end{array}$ & $\begin{array}{l}\text { - } \text { organizator publicznego transportu zbiorowego, } \\
\text { - realizacja polityki transportowej miasta Poznania, } \\
\text { - } \text { administracja zadań transportowych, } \\
\text { - realizacja procesów inwestycyjnych z zakresu infra- } \\
\text { struktury transportowej; }\end{array}$ \\
\hline ZM SELEKT & $\begin{array}{l}\text { Związek mię- } \\
\text { dzygminny }\end{array}$ & $\begin{array}{l}\text { - odbiór i zagospodarowanie odpadów komunalnych } \\
\text { z terenu gmin należących do związku; }\end{array}$ \\
\hline ZM. GOAP & $\begin{array}{l}\text { Związek mię- } \\
\text { dzygminny }\end{array}$ & $\begin{array}{l}\text { - odbiór i zagospodarowanie odpadów komunalnych } \\
\text { z terenu gmin należących do zwiazku; }\end{array}$ \\
\hline SGIPW & $\begin{array}{l}\text { Stowarzysze- } \\
\text { nie }\end{array}$ & $\begin{array}{l}\text { - reprezentowanie interesów wielkopolskich gmin } \\
\text { i powiatów na forum krajowym i europejskim, } \\
\text { - inicjowanie i wspieranie przedsięwzięć w dziedzi- } \\
\text { nach społeczno-gospodarczych, } \\
\text { - } \text { wspieranie rozwoju gospodarczego regionu oraz } \\
\text { promocja gmin i powiatów, } \\
\text { - promocja Wielkopolski i umacnianie tożsamości re- } \\
\text { gionalnej; }\end{array}$ \\
\hline $\begin{array}{l}\text { Metropolia } \\
\text { znań }\end{array}$ & $\begin{array}{l}\text { Stowarzysze- } \\
\text { nie }\end{array}$ & $\begin{array}{l}\text { - wspieranie idei samorządu terytorialnego oraz obro- } \\
\text { na wspólnych interesów członków stowarzyszenia, } \\
\text { - wspieranie rozwoju społeczno-gospodarczego Aglo- } \\
\text { meracji oraz współpracy gmin i powiatów w tym } \\
\text { zakresie, } \\
\text { - realizacja programów operacyjnych jako Związek } \\
\text { Zintegrowanych Inwestycji Terytorialnych, } \\
\text { - prowadzenie działań na rzecz powołania związku } \\
\text { zrzeszającego jednostki samorządu terytorialnego } \\
\text { tworzące Aglomerację; }\end{array}$ \\
\hline Aquanet & Spółka & $\begin{array}{l}\text { - pobór, uzdatnianie i dostarczanie wody, } \\
\text { - odbiór i oczyszczanie ścieków; }\end{array}$ \\
\hline
\end{tabular}




\begin{tabular}{|c|c|c|}
\hline 1 & 2 & 3 \\
\hline $\begin{array}{l}\text { Grupa } \\
\text { Zakupowa: } \\
\text { elektrycznej }\end{array}$ & $\begin{array}{l}\text { Porozumienie } \\
\text { międzygmin- } \\
\text { ne }\end{array}$ & $\begin{array}{l}\text { - przygotowanie i ogłoszenie jednego przetargu na } \\
\text { zakup energii elektrycznej dla gmin i podmiotów } \\
\text { gospodarczych, } \\
\text { - obejmuje swym zasięgiem łącznie } 15 \text { gmin i } 42 \text { pod- } \\
\text { mioty. }\end{array}$ \\
\hline
\end{tabular}

Źródło: Opracowanie własne.

Tabela 2

\section{Czlonkostwo gmin MOF w wybranych międzygminnych formach współpracy na terenie Aglomeracji Poznańskiej}

\begin{tabular}{|c|c|c|c|c|c|c|c|c|}
\hline MOF & 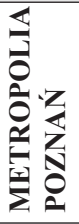 & 匇 & $\underset{\mathbf{N}}{\sum}$ & 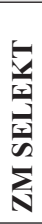 & 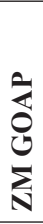 & है & 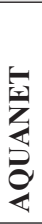 & 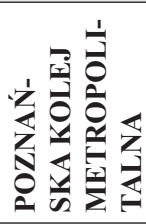 \\
\hline Buk & $\mathrm{X}$ & & & & $\mathrm{X}$ & & & $\mathrm{X}$ \\
\hline Czerwonak & $\mathrm{X}$ & & $\mathrm{X}$ & & $\mathrm{X}$ & $\mathrm{X}$ & $\mathrm{X}$ & $\mathrm{X}$ \\
\hline Dopiewo & $\mathrm{X}$ & $\mathrm{X}$ & $\mathrm{X}$ & $\mathrm{X}$ & & $\mathrm{X}$ & & $\mathrm{X}$ \\
\hline Kleszczewo & $\mathrm{X}$ & $\mathrm{X}$ & & & $\mathrm{X}$ & & & $\mathrm{X}$ \\
\hline Komorniki & $\mathrm{X}$ & & $\mathrm{X}$ & $\mathrm{X}$ & & $\mathrm{X}$ & & $\mathrm{X}$ \\
\hline Kostrzyn Wielkopolski & $\mathrm{X}$ & & & & $\mathrm{X}$ & & & $\mathrm{X}$ \\
\hline Kórnik & $\mathrm{X}$ & $\mathrm{X}$ & $\mathrm{X}$ & & & $\mathrm{X}$ & $\mathrm{X}$ & $\mathrm{X}$ \\
\hline Luboń & $\mathrm{X}$ & $\mathrm{X}$ & $\mathrm{X}$ & & & $\mathrm{X}$ & $X$ & $\mathrm{X}$ \\
\hline Mosina & $\mathrm{X}$ & $\mathrm{X}$ & $\mathrm{X}$ & $\mathrm{X}$ & & $\mathrm{X}$ & $\mathrm{X}$ & $\mathrm{X}$ \\
\hline Murowana Goślina & $\mathrm{X}$ & $\mathrm{X}$ & $\mathrm{X}$ & & $\mathrm{X}$ & & $\mathrm{X}$ & $\mathrm{X}$ \\
\hline Oborniki & $\mathrm{X}$ & $\mathrm{X}$ & & & $\mathrm{X}$ & $\mathrm{X}$ & & $\mathrm{X}$ \\
\hline Pobiedziska & $\mathrm{X}$ & $\mathrm{X}$ & & & $\mathrm{X}$ & $\mathrm{X}$ & & $\mathrm{X}$ \\
\hline Poznań & $\mathrm{X}$ & $\mathrm{X}$ & $\mathrm{X}$ & & $\mathrm{X}$ & $\mathrm{X}$ & $\mathrm{X}$ & $X$ \\
\hline Puszczykowo & $X$ & $\mathrm{X}$ & $\mathrm{X}$ & $\mathrm{X}$ & & $\mathrm{X}$ & $X$ & $X$ \\
\hline Rokietnica & $\mathrm{X}$ & & $\mathrm{X}$ & $\mathrm{X}$ & & & & $X$ \\
\hline Skoki & $\mathrm{X}$ & $\mathrm{X}$ & & & & $\mathrm{X}$ & & $\mathrm{X}$ \\
\hline Stęszew & $\mathrm{X}$ & & & $\mathrm{X}$ & & & & $\mathrm{X}$ \\
\hline Suchy Las & $\mathrm{X}$ & $\mathrm{X}$ & $\mathrm{X}$ & & & & $\mathrm{X}$ & $\mathrm{X}$ \\
\hline Swarzędz & $\mathrm{X}$ & $\mathrm{X}$ & $\mathrm{X}$ & & $\mathrm{X}$ & $\mathrm{X}$ & $\mathrm{X}$ & $\mathrm{X}$ \\
\hline Szamotuły & $\mathrm{X}$ & & & & & $\mathrm{X}$ & & $\mathrm{X}$ \\
\hline Śrem & $\mathrm{X}$ & $\mathrm{X}$ & & & & $\mathrm{X}$ & & $\mathrm{X}$ \\
\hline Tarnowo Podgórne & $\mathrm{X}$ & $\mathrm{X}$ & $\mathrm{X}$ & $\mathrm{X}$ & & $\mathrm{X}$ & & $X$ \\
\hline Powiat Poznański* & & $\mathrm{X}$ & & & & & & $\mathrm{X}$ \\
\hline
\end{tabular}

*_ gminy powiatu a nie sam powiat należą do MOF;

$\mathrm{x}$ - oznacza członkostwo $\mathrm{w}$ danej formie współpracy.

Źródło: Opracowanie własne. 
Powyższe opracowania ukazują przykłady międzygminnej współpracy na terenie aglomeracji poznańskiej. Warto zauważyć, że pośród gmin kwalifikowanych do Miejskiego Obszaru Funkcjonalnego Miasta Poznania - tabela 2 - nie ma żadnej, która nie brałaby udziału w jakiejkolwiek formie kooperacji. Część gmin przy pomocy dwóch związków międzygminnych wykonuje swoje zadania w zakresie gospodarki odpadami komunalnymi. Gminy niebędące członkami związku międzygminnego utworzyły swój system odbioru i zagospodarowania odpadów. Zdecydowana większość gmin w różnym zakresie współpracuje z miastem Poznaniem w oparciu o porozumienie międzygminne w dziedzinie zbiorowego transportu publicznego. Gminy nie współpracujące albo mają swój system komunikacji zbiorowej obsługujący ich teren, np. Oborniki, lub też nie mają potrzeby organizowania transportu zbiorowego np. Buk. Mieszkańcy tych gmin dojeżdżając do Poznania korzystają z własnych środków komunikacji lub też z dostępnej oferty kolejowych przewoźników realizujących przewozy regionalne np. Przewozy Regionalne czy też Koleje Wielkopolskie. Wszystkie gminy, widząc konieczność ściślejszej koordynacji polityki transportowej w zakresie transportu publicznego, są partnerami realizowanego pod auspicjami stowarzyszenia Metropolia Poznań i Urzędu Marszałkowskiego projektu Poznańskiej Kolei Metropolitalnej. Realizacją zadań z zakresu zbiorowego zaopatrzenia w wodę oraz odbioru i oczyszczania ścieków komunalnych zajmuje się spółka Aquanet, która większościowy pakiet udziałowy ma w 9 z 17 gmin aglomeracji poznańskiej. Pozostałe gminy mają swoje spółki komunalne podejmujące działalność w tym obszarze. Na uwagę zasługuje inicjatywa powołania grupy zakupowej na potrzeby zakupu energii elektrycznej i zaopatrzenia w gaz.

Przykłady działań integracyjnych o charakterze metropolitalnym, jak np. kolej metropolitalna, turystyka, zbiorowy transport publiczny, plan gospodarki niskoemisyjnej, plan gospodarki mieszkaniowej, metropolitalna koncepcja kierunków rozwoju przestrzennego, założenia polityki parkingowej P+R zrzeszają zdecydowaną większość gminy stowarzyszenia. Dotychczasowe osiąnnięcia integracyjne charakteryzuje duża siła przyciągania gmin spoza poznańskiego MOF np. gmina Czempiń, Brodnica, Kościan.

Gminy współpracując ze sobą wykorzystują do tego modele ponadgminnej integracji przewidziane w ustawie o samorzadzie gminny, lub też inne zgodne $\mathrm{z}$ prawem rozwiązania ${ }^{3}$ jak np. powołanie spółki komunalnej, inicjowanie powstania grup zakupowych.

${ }^{3}$ O polskim modelu gospodarki komunalnej czytaj: Krasnowolski, 2012; Ustawa z dnia 20 grudnia 1996 r. o gospodarce komunalnej. 


\section{Modele ponadgminnej integracji}

Zgodnie z ustawą o samorzadzie gminnym na terenie kraju możliwe są następujące formy integracji działań JST.

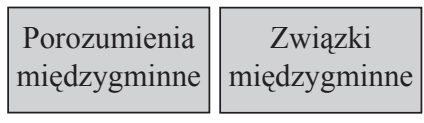

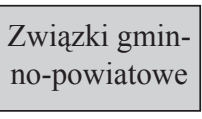

\author{
Centra Usług \\ Wspólnych
}

Stowarzyszenia gmin, powiatów

Ryc. 1. Ustawowe formy realizacji zadań na ponadgminnym poziomie Źródło: Opracowanie własne na podstawie: Ustawa z dnia 8 marca 1990 r. o samorzqdzie gminnym, Dz. U. 2015, poz. 1515.

Można je podzielić, stosując różne kryteria. Po pierwsze, ze względu na charakter występujących powiązań między gminami. Po drugie, ze względu na przedmiot współpracy. Interesujące byłyby badania stosujące jeszcze inne kryterium analizy: legitymacji podejmowanych przez uprawnione organy decyzji, stopnia powiązań funkcjonalnych między kooperującymi gminami. Tego typu analizy mogą służyć rozwianiu wątpliwości zgłaszanych przez mniejsze gminy obszarów metropolitalnych, których zarządzający moga podzielać obawy związane z ograniczeniem swojego wpływu na podejmowane decyzje przekładające się na standard życia ich mieszkańców i kontroli nad przekazanymi kompetencjami. Gminy aglomeracji poznańskiej do czasu noweli przedmiotowej ustawy wykorzystywały wszystkie przewidziane w niej formy współpracy. Dwie nowe możliwości: centra usług wspólnych i związki gminno-powiatowe, są rozwiązaniami postulowanymi przez środowisko samorządowców. W kontekście aglomeracji poznańskiej mogą być wykorzystywane, lecz na dzień dzisiejszy żadne z nich nie jest oficjalnie przedmiotem dyskusji $\mathrm{w}$ gronie włodarzy gmin aglomeracji.

\subsection{Stowarzyszenia - wspólnota celów i niewiążących decyzji}

Członkostwo gmin w stowarzyszeniach gminnych czy też tych z udziałem powiatów i/lub województw jest dość powszechnym sposobem na identyfikację i obronę wspólnych interesów. Członkostwo w stowarzyszeniu jest dobrowolne, wiąże się z określonym rodzajem korzyści dla gminy. Zgodę na przystąpienie przez gminę do stowarzyszenia wyraża rada gminy $\mathrm{w}$ formie uchwały. $\mathrm{Z}$ reguły członkostwo w stowarzyszeniu jest związane 
z uiszczaniem składki członkowskiej, która jest przyjmowana przez władze stowarzyszenia i regulowana w przyjęty sposób. Na terenie miejskiego obszaru funkcjonalnego miasta Poznania działa wiele stowarzyszeń z udziałem gmin z tego obszaru. Wsparciem działań aglomeracyjnych zajmuje się powołane w 2011 roku stowarzyszenie Metropolia Poznań. Jego działalność ma na celu opracowanie studiów i analiz dotyczących obszaru działania wraz z rekomendacjami co do kierunków działań strategicznych. Metropolia Poznań to stowarzyszenie, które w imieniu gmin występuje o środki zewnętrzne na swoje projekty. Aktualnie, zgodnie z decyzją członków stowarzyszenia, jest ono jednostką Miejskiego Obszaru Funkcjonalnego odpowiedzialną za wypracowanie, wdrożenie i rozliczenie strategii ZIT i realizowanych na jej podstawie programów regionalnych. Przykłady tych działań zawiera poniższa tabela.

Tabela 3

Ramowy harmonogram naborów wniosków na lata 2015-2022 składanych w trybie konkursowym w ramach ZIT

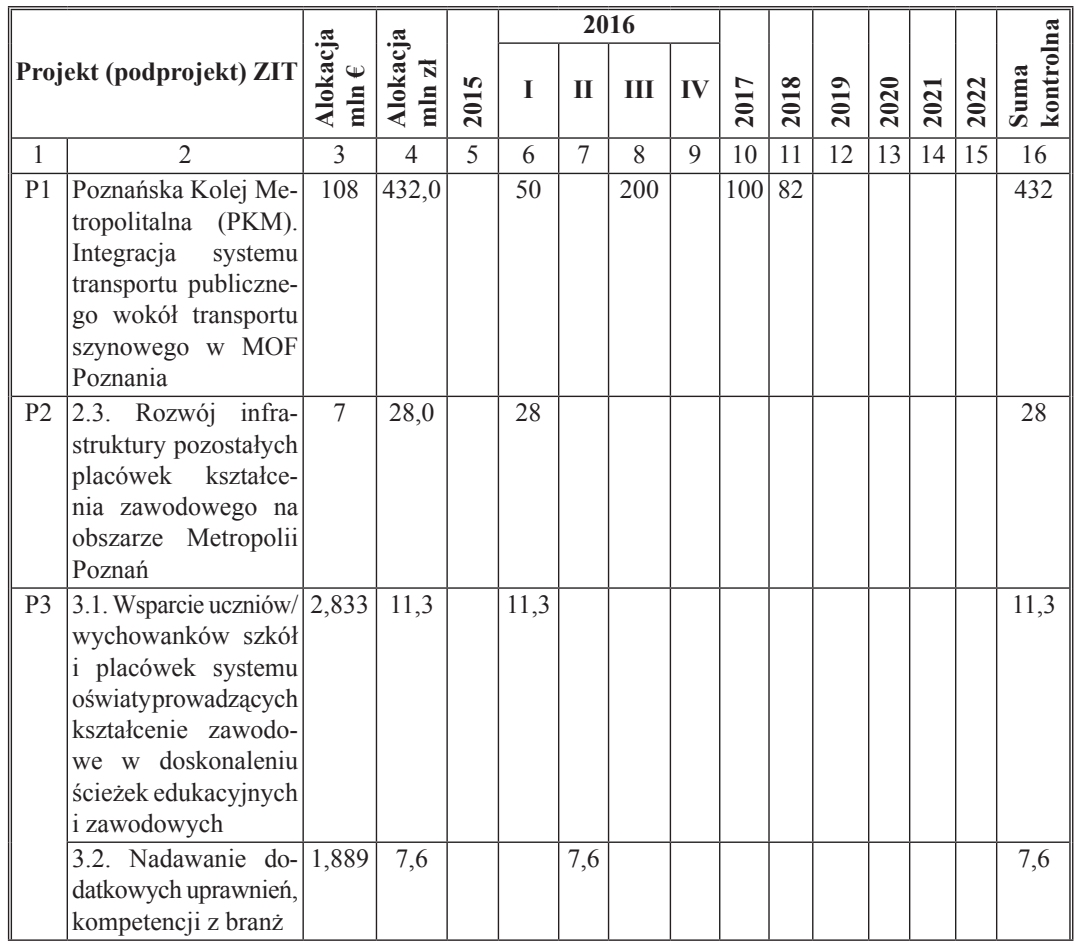




\begin{tabular}{|c|c|c|c|c|c|c|c|c|c|c|c|c|c|c|c|}
\hline 1 & 2 & 3 & 4 & 5 & 6 & 7 & 8 & 9 & 10 & 11 & 12 & 13 & 14 & 15 & 16 \\
\hline & $\begin{array}{l}\text { kluczowych dla roz- } \\
\text { woju Miejskiego Ob- } \\
\text { szaru Funkcjonalnego } \\
\text { Poznania }\end{array}$ & & & & & & & & & & & & & & \\
\hline P4 & $\begin{array}{l}4.1 . \text { „Gimnazjalista } \\
\text { z pasją"-Komplekso- } \\
\text { we wsparcie uczniów } \\
\text { gimnazjów w wy- } \\
\text { borze optymalnych } \\
\text { ścieżek edukacyjnych } \\
\text { i zawodowych }\end{array}$ & 3 & 12,0 & 12 & & & & & & & & & & & 12 \\
\hline & $\begin{array}{|lr|}4.2 . & \text { Wsparcie na- } \\
\text { uczania } & \text { matematyki } \\
\text { i informatyki w } & \text { gim- } \\
\text { nazjach } \quad \mathrm{i} & \text { szkołach } \\
\text { ponadgimnazjalnych }\end{array}$ & 1,351 & 5,4 & & 5,4 & & & & & & & & & & 5,4 \\
\hline P7 & $\begin{array}{l}\text { 7.2. Rozbudowa sys- } \\
\text { temu tras rowerowych } \\
\text { na obszarze funkcjo- } \\
\text { nalnym Poznania }\end{array}$ & 8 & 32,0 & & & 10 & & & 12 & 10 & & & & & 32 \\
\hline P8 & 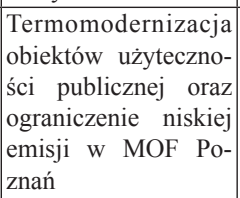 & 16 & 64,0 & & & 40 & & & & 24 & & & & & 64 \\
\hline P9 & $\begin{array}{l}\text { Ochrona i moderni- } \\
\text { zacja obiektów uży- } \\
\text { teczności publicznej } \\
\text { stanowiących dzie- } \\
\text { dzictwo kulturowe }\end{array}$ & 8,4 & 33,6 & & & & 33,6 & & & & & & & & 33,6 \\
\hline P10 & $\begin{array}{l}\text { Poprawa dostepu do } \\
\text { wysokiej jakości usług } \\
\text { profilaktyki zdrowot- } \\
\text { nej w MOF Poznań }\end{array}$ & 3,758 & 15,0 & & & 7 & & & & & 8 & & & & 15 \\
\hline P11 & $\begin{array}{llr}\text { Poprawa dostępu do } \\
\text { usług opieki nad } \\
\text { dziećmi do lat } 3\end{array}$ & 4 & 16,0 & & & & 9 & & & 7 & & & & & 16 \\
\hline P12 & $\begin{array}{|lr|}\text { Poprawa } & \text { dostępu } \\
\text { do } \quad \text { usług } & \text { asystenta } \\
\text { rodzinnego } & \text { oraz ko- } \\
\text { ordynatora } & \text { rodzinnej } \\
\text { pieczy } & \text { zastępczej } \\
\text { w MOF Poznań } \\
\end{array}$ & 5,369 & 21,48 & 12 & & & & & & & 9,48 & & & & 21,48 \\
\hline
\end{tabular}

Źródło: Materiał z posiedzenia Rady Metropolii w dniu 6 listopada 2015, źródło własne.

Współpraca na szczeblu stowarzyszeń wymaga, jak wspomniano, zgody rady gminy. Angażuje podmioty do współpracy w ściśle określonym zakresie. Nie wiąże się z powołaniem nowego bytu prawnego, który 
realizowałby $\mathrm{w}$ imieniu własnym na rzecz gmin określone zadania publiczne. Zgodnie bowiem z art. 84 ust. 1 ustawy o samorzadzie gminnym, stowarzyszenia gmin są powoływane w celu wspierania idei samorządu terytorialnego oraz obrony wspólnych interesów (usg, art. 84). W tym kontekście nie powstaje zasadniczy problem legitymacji podejmowanych decyzji. Stąd też za wystarczające uznać można tradycyjne instrumenty kontroli nad działaniami stowarzyszenia, jak i realizowaną przez nie polityką. Chęć wzmocnienia współpracy w dziedzinie dotyczącej wykonywanych zadań publicznych wymusza zastosowanie innej formuły prawnej.

Zgodnie z przyjętym modelem realizacji Zintegrowanych Inwestycji Terytorialnych, beneficjentem przekazanych środków finansowych mogą być tzw. związki ZIT działające $\mathrm{w}$ formule stowarzyszenia, związku międzygminnego. W sytuacji, w której stowarzyszenie gmin staje się podmiotem pełniącym zadania związku ZIT ${ }^{4}$, kwestia wpływu i kontroli podejmowanych decyzji powinna być na nowo przemyślana. Pomimo tego, że celem stowarzyszenia nie jest realizacja przez nie zadań publicznych, to już decydowanie o dystrybucji środków w takich dziedzinach jak transport publiczny, polityka edukacyjna, polityka społeczna, polityka ochrony środowiska $i$ in. wymaga refleksji nad formułą decyzyjną $i$ kontrolną. Otwartym pozostaje pytanie o legitymację organów stowarzyszenia do podejmowania tego rodzaju decyzji. Realizacja strategii ZIT, będzie testem na integrację gmin i ich zdolność do wieloaspektowej współpracy na wspólnotowym poziomie ponadgminnym. Zgodnie z logiką strategii ZIT, diagnozują one obszary wsparcia i na tej podstawie pozwalają na podejmowanie decyzji o wykorzystaniu autonomicznego wobec gmin znacznego budżetu inwestycyjnego. Środki przyznane na realizację ZIT, pomimo tego, że będą rozdzielane w trybie konkursowym, w zasadniczy sposób zdeterminują kierunki rozwoju gmin i całej aglomeracji. Ponadto wspierają realizację przez gminy określonych zadań publicznych, a te jak wiemy mogą być wykonywane przez gminy na szczeblu międzygminnym, lecz w innej formule organizacyjnej.

Innym przykładem koordynacji działań gmin w formule stowarzyszenia jest Poznańska Lokalna Organizacja Turystyczna. Na znaczenie turystyki w określaniu funkcji metropolitalnej zwracają uwagę autorzy opracowanej przez Centrum Badań Metropolitalnych analizy zatytułowanej Turystyka w aglomeracji poznańskiej (Bródka, Zmyślony, 2012). „W dużych mia-

4 Na przykład Metropolia Poznań na podstawie przyjętej uchwały przez Radę Metropolii (uchwała nr 3/2013). 
stach i aglomeracjach miejskich obserwuje się zjawisko integracji funkcji turystycznej z rekreacyjną. [...] Funkcja turystyczna należy do funkcji egzogenicznych, ma znaczenie i zasięg co najmniej ponadregionalny i polega na pełnieniu działalności usługowej najwyższego rzędu, zatem ma atrybuty funkcji metropolitalnej” (Zmyślony, 2012, s. 12). Działalność PLOT koncentruje się wokół promocji Poznania i aglomeracji poznańskiej jako miejsca atrakcyjnego turystycznie, wspierania rozwoju rynku turystycznego w tym regionie, wzmacniania współpracy pomiędzy administracją a branżą turystyczna, instytucjami kulturalnymi oraz podmiotami gospodarczymi. $\mathrm{Na}$ dzień dzisiejszy członkostwo PLOT oprócz podmiotów z prywatnego sektora jest udziałem 15 gmin i jednego powiatu z 22 gmin zaliczanych do Miejskiego Obszaru Funkcjonalnego Miasta Poznania.

Innym przykładem integracji zarówno reprezentującej interesy wielkopolskich gmin i powiatów na forum krajowym i europejskim, jak również inicjującej i wspierającej przedsięwzięć w dziedzinach społeczno-gospodarczych oraz wspierającej rozwój gospodarczy regionu oraz promocję gmin i powiatów jest działalność Stowarzyszenia Gmin i Powiatów Wielkopolski. Członkostwo w tym stowarzyszeniu oprócz pozostałych gmin województwa Wielkopolskiego deklaruje 16 z 22 gmin MOF Poznania.

2.2. Porozumienia międzygminne - związki międzygminne - modele ściślejszej integracji ograniczającej przedmiotowo suwerenność gmin

Zawierane przez gminy w sprawach powierzenia jednej z nich określonych zadań publicznych, porozumienia międzygminne, są modelem ograniczającym przedmiotowo ich kompetencje w określonej dziedzinie. Powierzenie wykonywania zadań publicznych objętych porozumieniem wskazanej w nim gminie, wiąże się z przejęciem przez nią praw i obowiązków oraz udziałem w kosztach realizacji powierzonego zadania. Wyróżnić można porozumienia dwu- i wielostronne. Na skutek zawartego porozumienia, gmina na którą scedowano uprawnienia może w celu ich realizacji powołać nową jednostkę organizacyjną dedykowaną określonym czynnościom. Może też rozszerzyć zakres spraw realizowanych przez już istniejącą jednostkę. Celem porozumienia między gminami jest określenie, wypracowanie, przyjęcie i wdrożenie rozwiązań organizacyjno-prawnych, które działają z korzyścią dla wszystkich beneficjentów. Ten model integracji zadań publicznych może prowadzić do wzmocnienia pozycji regionalnej gmin objętych porozumieniem. 
Wykonywanie zadań w oparciu o formułę porozumienia międzygminnego wiąże się z ograniczeniem wpływu gmin na dalszy bieg spraw w tej dziedzinie i wymaga zmiany sposobu zarządzania i koordynacji. Oczywistym jest, że przeniesienie kompetencji na rzecz drugiej gminy jest procesem możliwym do odwrócenia. To gminie przypisywana jest pierwotna i pełna kompetencja ustawowa. To rada gminy w drodze uchwały określa zakres i charakter przekazanej kompetencji. Może też w drodze uchwały ją cofnąć. Określa instrumenty nadzoru nad wykonaniem przekazanej kompetencjis. Warto zauważyć, że ,[...] ustawodawca nie przewiduje żadnych instrumentów prawnych umożliwiających przedstawicielom gminy przekazującej zadania wpływania na treść rozstrzygnięć podejmowanych przez organy gminy przejmującej zadania. [...] Tym samym pominięcie przez organy gminy przejmującej opinii struktur doradczych [gminy przekazującej - przyp. M. T.] nie wpływa na ważność podejmowanych rozstrzygnięć - zarówno uchwał, jak i decyzji administracyjnych" (por. Kiełbus, Kostrzewska, 2012). Formuła porozumienia międzygminnego może jednak stanowić alternatywę dla gmin, które chcą ze sobą współpracować, jednak z różnych przyczyn nie decydują się na zacieśnienie współpracy i powołanie związku międzygminnego. Część gmin aglomeracji poznańskiej współpracuje ze sobą w oparciu o wielostronne porozumienie międzygminne m.in. w dziedzinie organizacji zbiorowego transportu publicznego. Scedowane na miasto Poznań kompetencje $\mathrm{w}$ tym zakresie pozwalają na funkcjonowanie jednolitego systemu koordynacji i zarządzania, na realizację usług zbiorowego transportu publicznego w oparciu o jeden regulamin przewozów, jedną taryfę biletową. Współpraca ta odbywa się z korzyścią dla mieszkańców aglomeracji, podnosi komfort życia i wzmacnia ich mobilność.

Innym przykładem wspólnego wykonywania zadań i przekazywania kompetencji gminy, jest formuła związku międzygminnego (usg, rozdz. 7). Gminy decydując się na powołanie związku przypisują jego organom określone funkcje i zadania. Statut związu, po obligatoryjnym uzgodnieniu $\mathrm{z}$ wojewoda, określa prawa i obowiązki gmin w nim uczestniczących. Nadaje mu osobowość prawną, określa szczegółowe kompetencje zarządu i może doprecyzować kompetencje zgromadzenia związku. Zarząd związku w imieniu gmin członkowskich wykonuje

${ }^{5}$ Kwestią otwartą pozostaje sposób w jaki wójt, burmistrz, prezydent miasta z nich korzysta. Rola rady gminy w tej formie współpracy, sprowadza się do przyjęcia uchwały o zawarciu porozumienia, zapewnienia środków na jego realizację i ewentualnie przyjęcia uchwały o wystąpieniu z porozumienia. 
kompleksowo powierzone zadania z pożytkiem dla gmin i całego związku. Podobnie jak w przypadku porozumień międzygminnych decyzję o współtworzeniu związku międzygminnego podejmuje rada gminy, która również zachowuje swoje prawo do decyzji o wystapieniu ze związku lub też w formie pisemnej może zablokować zmianę jego statutu. Rada ta zachowuje pośredni wpływy na działania związku. W odróżnieniu od współpracy w oparciu o porozumienie międzygminne, bezpośrednie przełożenie na prowadzoną politykę, jak i nadzór nad jej wykonaniem zyskuje wójt, burmistrz, prezydent miasta członkowskiego. Bierze on udział w pracach zgromadzenia związku lub w jego zarządzie. Ponadto ma on wpływ na decyzje strategiczne podejmowane zwyczajowo przez Zgromadzenie Związku, w którym każda z gmin dysponuje jednym gło$\mathrm{sem}^{6}$. Warto jednak pamiętać, iż zgodnie z art. 70 ust. 2 ustawy $o$ samorzadzie gminnym (usg, art. 70 ust. 2) w pracach Zgromadzenia moga uczestniczyć dwaj reprezentanci gmin. Jeśli taką możliwość przewiduje statut związku, to drugiego przedstawiciela wskazuje rada gminy ${ }^{7}$. Decyzja o podwójnej legitymacji decyzji jest uzależniona od woli politycznej członków związku, jak i od ich doświadczeń płynących z wcześniejszej współpracy. Nie mniej ważnym elementem, który upodmiotowia gminy $\mathrm{w}$ formule związku, jest system podejmowania decyzji. Zaproponowany na przykład w ustawie $o$ zwiqzkach metropolitalnych model, zachęca do jednomyślności przedstawicieli jednej gminy, uznając dwugłos za głos wstrzymujący się. Wskazuje również na system podwójnej większości, uzależniając wagę głosu od liczby mieszkańców danej gminy.

Na znaczenie powyższych dylematów zwracają uwagę włodarze miast, którzy stając na straży interesu swoich mieszkańców dość ostrożnie podchodzą do zagadnienia współpracy ponadgminnej, zwłaszcza $\mathrm{w}$ formule, w której liderem jest znacząco większa gmina. Obawiając się marginalizacji w tak skonstruowanym związku mniejsze gminy, pomimo presji integracyjnej, są jej niechętne uzależniając swoje członkostwo od innych czynników. Takie obawy są domeną nie tylko polskich samorzą-

${ }^{6}$ Możliwe są również inne konfiguracje reprezentacji gmin.

7 Przy takim składzie Zgromadzenia, przynajmniej teoretyczny wpływ na prace związku, kontrolę nad jego działaniami zyskują bezpośrednio rady gminy, które przecież są przedstawicielskimi organami stanowiącymi w imieniu mieszkańców obszaru, na którym działa związek. Ma to dość ważne znaczenie z punktu widzenia podejmowania przez rady gmin uchwał w sprawach związku. Mogą one procedować m.in. w sprawie zmiany statutu związku, czy też o wysokość dotacji gminnej przeznaczanej na działania statutowe. 
dów. Na przykład gminy landu Brandenburgia tworzące razem z Berlinem związek komunalny publicznej komunikacji zbiorowej, wskazują na dominującą w związku pozycję Berlina, determinującą kierunki rozwoju polityki zbiorowego transportu publicznego. Tomasz Kaczmarek, wskazując bariery we współpracy ponadgminnej określa je jako: lęk małych gmin przed „efektem wymywania” (,backwash effect”); obawy dużego miasta przed utratą części kompetencji (,administrative shadow of hierarchy"); różnice interesów między szczeblami samorządu; brak consensusu politycznego; przesadne ambicje lokalne; antagonizmy społeczne (por. Kaczmarek, 2013).

W odróżnieniu od współpracy w oparciu o porozumienia międzygminne, model związku międzygminnego poprzez udział w pracach zgromadzenia związku włodarzy gmin i/lub przedstawiciela rad gmin, daje im potencjalnie większy wpływ na podejmowane decyzje. W podobnym tonie wypowiadają się eksperci z kancelarii prawnej Kiełbus i Wspólnicy (por. Kiełbus, Kostrzewska, 2012). „Związek komunalny, mając bardziej sformalizowany charakter, zapewnia przedstawicielom wszystkich gmin członkowskich realny udział w podejmowaniu decyzji. [...] W konsekwencji udział przedstawicieli wszystkich współpracujących ze sobą gmin może korzystnie wpłynąć na poziom społecznej akceptacji podejmowanych rozstrzygnięć przez organy mające legitymację wszystkich społeczności lokalnych"».

Przykładem integracji w formule związku międzygminnego na obszarze MOF Poznania może być zrzeszenie gmin w Związku Międzygminnym GOAP lub też Związku Selekt. Oba działają w obszarze odbioru i zagospodarowania odpadów komunalnych z gmin będących ich członkami.

W wyniku ostatniej nowelizacji ustawy o samorzadzie gminnym, gminy zyskały możliwość wykonywania swych zadań publicznych w oparciu

8 „Wynika to bezpośrednio z bezwzględnie obowiązujących regulacji ustawowych, których stosowanie nie może być wyłączone ani ograniczone postanowieniami statutu związku. [Ponadto] [przyp. M. T] zgodnie z art. 70 ust. 1 usg, w skład organu uchwałodawczo-kontrolnego związku (zgromadzenia związku) wchodzą wójtowie (burmistrzowie, prezydenci miast) wszystkich gmin uczestniczących w związku (o ile rada gminy na wniosek organu wykonawczego nie umocuje w tym zakresie do reprezentacji gminy zastępcy wójta lub jednego z radnych) [...]. Dodatkowo realny wpływ poszczególnych przedstawicieli gmin na decyzje podejmowane przez władze związku wynika z instytucji sprzeciwu (przewidzianej w art. 72 usg), która daje podstawę zgłoszenia weta w stosunku do każdej uchwały zgromadzenia związku" (Kiełbus, Kostrzewska, 2012). 
o formułę centrów usług wspólnych, jak i w formule związków gminnopowiatowych. Dla tego pierwszego rozwiązania ustawodawca wskazuje, że celem funkcjonującego na zasadzie związku międzygminnego centrum usług wspólnych jest wykonywanie określonych zadań publicznych. Decyzję o współpracy podejmują zainteresowane rady gmin, zaś szczegółowe zasady reguluje uzgodniony z wojewodą i poparty bezwzględną liczbą głosów członków rad gmin, statut (usg, art. 64 ust. 1). Aktualnie żadna z gmin z MOF miasta Poznania nie nawiązała współpracy w oparciu o to rozwiązanie.

2.3. Związki metropolitalne - nowa formuła integracji zadań gmin

Związek metropolitalny (ustawa o zwiqzkach metropolitalnych, art. 1) jest wykonującym zadania publiczne zrzeszeniem jednostek samorządu terytorialnego $\mathrm{w}$ danym obszarze metropolitalnym. Związek wykonuje zadania publiczne polegające na kształtowaniu ładu przestrzennego poprzez przyjęcie ogólnego studium uwarunkowań rozwoju przestrzennego obszaru metropolitalnego, rozwoju obszaru związku, publicznego transportu zbiorowego na obszarze związku poprzez powierzenie organizacji publicznego transportu zbiorowego na mocy porozumienia $\mathrm{z}$ gminami lub powiatami; współdziałanie w ustalaniu przebiegu dróg krajowych i wojewódzkich, promocji obszaru metropolitalnego. Związek może być tworzony przez gminy położone w granicach obszaru metropolitalnego, jak i powiaty na obszarze których leży co najmniej jedna gmina położona w jego granicach. Podmiotem odpowiedzialnym za tworzenie obszaru metropolitalnego i działającego na nim związku jest Rada Ministrów (uzm, art. 4). W drodze rozporządzenia ustala ona granice, tworzy związki, biorąc pod uwagę ustalenia Koncepcji Przestrzennego Zagospodarowania Kraju oraz planu zagospodarowania przestrzennego województwa. Ponadto kryterium decydującym są powiązania funkcjonalne oraz zaawansowanie procesów urbanizacyjnych, jednorodność układu osadniczego i przestrzennego powstałego z uwzględnieniem więzi społecznych, gospodarczych i kulturowych. Ustawodawca wprowadza ponadto kryterium demograficzne: 500000 tysięcy mieszkańców, którzy muszą zamieszkiwać obszar na którym może być powołany związek metropolitalny. Zgodnie z KPZK definiuje obszar metropolitalny uznając za taki spójną pod względem przestrzennym strefę oddziaływania miasta będącego siedzibą wojewody lub sejmiku województwa, charakteryzującą się 
istnieniem silnych powiązań funkcjonalnych oraz zaawansowania procesów urbanizacyjnych (uzm, art. 5). Przed powołaniem związku istotne są konsultacje rad gmin z mieszkańcami, ponadto konsultacje z radami powiatów, sejmikiem województwa i z wojewodą.

W celu wykonywania przypisanych kompetencji związek może tworzyć jednostki organizacyjne, zawiązywać stowarzyszenia, porozumienia czy też współpracować ze związkami metropolitalnymi z innych państw.

Organami związku jest zgromadzenie i zarząd. Wybrane uprawnienia zarządu i zgromadzenia zawiera tabela 4.

Tabela 4

\section{System instytucjonalny związku metropolitalnego}

\begin{tabular}{|c|c|}
\hline$\overline{\text { ZgI }}$ & \\
\hline \begin{tabular}{|l} 
- \\
- organ stanożony z dwóch delegatów gmin i powia- \\
tów wchodzących w skład związku; \\
- prawo delegacji mają wójtowie, burmi- \\
strzowie lub prezydenci miast i starosto- \\
wie oraz wybrani (po jednym z każdej \\
gminy, powiatu) przedstawiciele rad gmin \\
i powiatów; \\
- uchwały podejmuje kwalifikowaną więk- \\
szością głosów; \\
- kwalifikowana większość głosów jest \\
osiagnięta przy większości głosów przed- \\
stawicieli JST związku i jednoczesnej \\
takiej liczby gmin, których mieszkańcy \\
stanowią większość ludności zamieszka- \\
łej na obszarze zwiazku.
\end{tabular} & 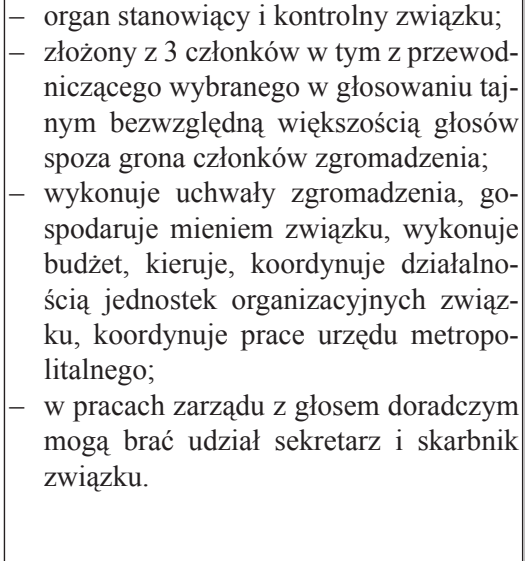 \\
\hline
\end{tabular}

Źródło: Opracowanie własne na podstawie: ustawa o zwiqzkach metropolitalnych.

Zgromadzenie podejmuje uchwały m.in. w następujących sprawach:

- strategii rozwoju związku metropolitalnego;

- statutu związku;

- ramowego studium uwarunkowań rozwoju przestrzennego związku;

- budżetu związku;

- rozpatrzenia sprawozdań z wykonania budżetu;

- wyboru i odwołania członków zarządu;

- ustalenia wynagrodzenia przewodniczącego zgromadzenia. Związek dysponuje budżetem składającym się z 5\% udziału w podatku PIT mieszkańców gmin związku, składek gmin obliczonych na pod- 
stawie wskazanego w ustawie algorytmu, dochodów uzyskiwanych przez metropolitalne jednostki budżetowe oraz wpłaty od metropolitalnych zakładów budżetowych, odsetek od pożyczek udzielonych wchodzącym w skład związku gminom, dotacji z budżetu państwa oraz spadków, darowizn na rzecz związku.

Na obszarze aglomeracji poznańskiej powołanie związku znajduje swoich zwolenników. Zwrócić należy uwagę chociażby na dyskutowaną już wolę powołania związku międzygminnego na potrzeby ściślejszej integracji zbiorowego transportu publicznego, czy też na zgłaszaną przez prezydenta Jacka Jaśkowiaka propozycję wypracowania wspólnej polityki transportowej. Zarówno dla pierwszej, jak i częściowo drugiej propozycji, związek może stanowić formułę integracji. Otwartą pozostaje kwestia woli wszystkich gmin tworzących aglomerację poznańską. Dla gmin współpracujących w dziedzinie zbiorowego transportu publicznego wystarczająca może być formuła porozumienia międzygminnego realizowana przez powołaną uchwałą Rady Miasta Poznania jednostkę budżetową - Zarząd Transportu Miejskiego. Utworzenie na tych doświadczeniach związku metropolitalnego lub związku międzygminnego ${ }^{9}$ wymaga powtórzenia debaty nad przyszłością aglomeracji poznańskiej, jej potencjałem, który wsparty tą formą organizacyjną, może być ważnym elementem budującym przewagę konkurencyjną aglomeracji. Kołem zamachowym tej integracji jest niewątpliwie dążenie gmin do stworzenia atrakcyjnej, wygodnej i dostosowanej do potrzeb mieszkańców aglomeracji oferty przewozowej, dzięki której zwiększy się liczba podróży odbywanych środkami transportu zbiorowego, a także przyczyni się do zmniejszenia poziomu kongestii transportowej i kosztów zewnętrznych (Szymczak, 2012, s. 8).

W kontekście woli wzmocnienia mobilności mieszkańców aglomeracji poznańskiej, zasadnicze są zmiany wprowadzone na podstawie analizowanej ustawy, do ustawy o publicznym transporcie zbiorowym (uptz, art. 5). W ich konsekwencji ustawodawca wyróżnia oprócz gminnych, powiatowych, wojewódzkich, międzywojewódzkich - metropolitalne przewozy pasażerskie. Za takie uznaje przewozy osób w ramach zbiorowego transportu publicznego, wykonywane w granicach związku metropolitalnego inne niż gminne, powiatowe, powiatowo-gminne, wojewódzkie i międzywojewódzkie (uptz, art. 5a). W myśl noweli ustawy,

${ }^{9}$ W 2009 roku niektóre gminy aglomeracji parafowały umowę o powołaniu międzygminnego związku komunikacyjnego. Związek powstał, jednak nie został zarejestrowany jego statut. Tym samym można uznać, że jest martwym podmiotem. 
organizatorem zbiorowego transportu publicznego może być związek metropolitalny, któremu powierzono to zadanie na mocy porozumienia z gminami lub powiatami. Zakres zadań organizacyjnych dotyczy linii komunikacyjnej albo sieci komunikacyjnej na danym obszarze. W celu lepszej organizacji i zarządzania siecią komunikacji metropolitalnej zadaniem związku jest opracowanie planu transportowego, który w dniu wejścia w życie zastępuje opracowane przez gminy, związki międzygminne, powiaty lub związki powiatów plany transportowe. Oczywistym jest, że metropolitalny plan transportowy musi uwzględniać jego wojewódzki odpowiednik i być skonsultowany z gminami, powiatami, związkami, które ewentualnie sąsiadują ze związkiem metropolitalnym.

Powstanie związku metropolitalnego na bazie Stowarzyszenia Metropolia Poznań wydaje się naturalną koleją rzeczy i krokiem w kierunku ściślejszej integracji. Gminy nie należące bezpośrednio w Miejskim Obszarze Funkcjonalnym miasta Poznania, mogłyby nawiązać współpracę ze związkiem w oparciu o porozumienie dwu- lub wielostronne. Takie porozumienie byłoby sensowne $\mathrm{np}$. w dziedzinie zbiorowego transportu publicznego. Dotychczas wypracowana formuła wielostronnych porozumień międzygminnych miałaby szanse na rozwój. Nie bez znaczenia pozostają kwestie upodmiotowienia w systemie decyzyjnym np. w zakresie polityki taryfowej czy też regulaminu przewozów, standaryzacji usług. Choć brak związku metropolitalnego tego nie wyklucza, to jego powołanie mogłoby przyspieszyć powstanie wspólnego koszyka zamówień dla operatorów systemu i służyć wypracowaniu wspólnej polityki rozwoju zbiorowego transportu publicznego $\mathrm{z}$ uwzględnieniem priorytetów inwestycyjnych $\mathrm{w}$ infrastrukturę techniczną, jak i elementy systemu, np. budowę i rozwój systemu parkingów $\mathrm{P}+\mathrm{R}$, czy też rozwój sieci roweru miejskiego. Działania te powinny być sprzężone ze strategicznym zarządzaniem miejskimi spółkami świadczącymi usługi zbiorowego transportu publicznego, dostosowującym jakość usług do standardów metropolitalnych, krajowych i europejskich.

Ponadto warto byłoby się zastanowić nad rozszerzeniem współpracy metropolitalnej o wspólny plan budowy dróg o znaczeniu międzygminnym, metropolitalnym, wspólną politykę oświatową obejmującą również politykę rynku pracy z uwzględnieniem uczelni wyższych i instytucji rynku pracy. Pod rozwagę poddać należy wspólny system gospodarki odpadami komunalnymi, aczkolwiek doświadczenia związku GOAP mogą niektóre gminy zniechęcać do takiej współpracy. System ten wiązałby się z konieczną zmianą zasad segregacji odpadów w tych gminach, które są 
członkami innych związków lub wdrożyły autonomiczny system i oddają odpady do innych instalacji regionalnych.

Wśród zalet współpracy w oparciu o rozwiązania związków międzygminnych lub związków metropolitalnych wymienić można następujące:

- wyraźne przekazanie realizacji zadań publicznych wyodrębnionemu pod względem organizacyjnym, prawnym i finansowym podmiotowi, którego głównym celem jest wykonywanie tych zadań. Zadania publiczne realizowane są zatem przez jeden podmiot na terenie wszystkich gmin tworzących związek. „Związek ten wykonuje przekazane mu zadania na rzecz gmin członkowskich we własnym imieniu i na własną odpowiedzialność. Posiada bowiem niezależną od gmin członkowskich osobowość prawną. W konsekwencji gminy uczestniczące w związku zwolnione zostają z nałożonych przez ustawodawcę obowiązków oraz konsekwencji prawnych za ich niewykonanie" (Kiełbus, Kostrzewska, 2012);

- przedstawicielski charakter organów związku międzygminnego co odróżnia związek od przekazania kompetencji w oparciu o porozumienie międzygminne. Ponadto minimalizuje się wówczas ryzyko negacji przez mieszkańców gminy przekazującej zadania rozstrzygnięć podejmowanych przez radnych gminy na którą scedowano uprawnienia;

- ujednolicenie działań podejmowanych na obszarze wszystkich gmin do niego należących co np. dla zbiorowego publicznego transportu ma zasadnicze znaczenie również w kontekście wspólnej taryfy przewozowej, jak i standardu świadczenia usług;

- sprawniejsza obsługa finansowo-księgowa, nie zakładająca jednak braku kontroli nad dystrybuowanymi w formie składki członkowskiej środkami publicznymi. Ponadto istnieje teoretyczna możliwość uzyskiwania oszczędności związanych z zakupem określonych usług służących realizacji zadań na terenie wszystkich gmin członkowskich;

- potencjalne obniżenie wydatków na gminną administrację na rzecz wspólnej bardziej profesjonalnej obsługi gwarantowanej przez związek, który będzie mógł wspierać specjalizację merytoryczną swoich pracowników.

\section{Rozwój Poznania poprzez lączenie z ościennymi gminami}

O pomyśle połączenia ościennych gmin z miastem Poznaniem dyskutowano już wielokrotnie podczas rozmów bilateralnych z przedstawicielami 
władz sąsiadujących bezpośrednio gmin. Wstępne rozmowy w tym temacie prowadzili ówczesny Prezydent Miasta Poznania Ryszard Grobelny oraz były Burmistrz Miasta Luboń Dariusz Szmyt. W ich trakcie zdecydowano o zacieśnianiu współpracy w oparciu o możliwe wówczas regulacje.

W ich efekcie Poznań i Luboń jako pierwsze miasta w 2010 roku zawarły porozumienie międzygminne w sprawie organizacji zbiorowego transportu publicznego. Forum dyskusji o nowych dziedzinach współpracy stanowiła formuła stowarzyszenia Metropolia Poznań.

W wyniku wyborów samorządowych z 2014 roku i zmiany na stanowisku Prezydenta Miasta Poznania, urzędujący prezydent Jacek Jaśkowiak powrócił za pośrednictwem środków masowego przekazu do tego pomysłu, forsując go z większym zaangażowaniem. Propozycja przyłączenia się do miasta Poznań została skierowana pod adresem gminy Suchy Las, Komorniki i Luboń. Propozycja jest oparta o zasady zawarte w art. 4 ustawy o samorzqdzie gminnym (usg, art. 4).

Decyzję o łączeniu gmin w oparciu o zgodny wniosek zainteresowanych gmin, po dopełnieniu obowiązku konsultacji z mieszkańcami lub po referendum lokalnym w tej sprawie podejmuje Rada Ministrów, wydając stosowne rozporządzenie. Do wniosku kierowanego za pośrednictwem wojewody na ręce ministra właściwego do spraw administracji publicznej należy dołączyć opinie rad gmin objętych wnioskiem, rady powiatu gdy wolę łączenia wyrażają gminy z dwóch różnych powiatów, jak również opinię samego wojewody.

W następstwie wydanego rozporządzenia Rada Ministrów na wniosek wojewody zgłoszony za pośrednictwem ministra właściwego do spraw administracji publicznej, wyznacza pełnomocnika do spraw połączenia gmin. Do czasu połączenia gmin zadaniem pełnomocnika jest przygotowanie organizacyjne i prawne gminy do wykonywania zadań publicznych, w tym przygotowanie projektu uchwały budżetowej gminy w trybie i na zasadach określonych w przepisach o finansach publicznych. $\mathrm{Z}$ dniem połączenia gmin pełnomocnik, przejmuje wykonywanie zadań i kompetencji ich organów do dnia wyboru nowych organów gminy tj. nowej rady gminy i nowego wójta, burmistrza lub prezydenta (usg, art. 4e).

Propozycja prezydenta miasta Poznania Jacka Jaśkowiaka wiązała się dodatkowo z finansowym bonusem integracyjnym, który przewiduje art. 41 i 41a ustawy o dochodach jednostek samorzadu terytorialnego (udjst). Przepisy ustawy przewidują w ,,art. 41 ust. 1 dla gminy powstałej w wyniku połączenia dwóch lub więcej gmin, w drodze zgodnych uchwał, wskaźnik udziału we wpływach z podatku dochodowego od osób 
fizycznych, określony w art. 4 ust. 2, w okresie 5 lat, począwszy od dnia 1 stycznia roku następującego po roku, w którym podjęto decyzję o połączeniu, jest zwiększony o pięć punktów procentowych". W wyniku nowelizacji przepisów, ustawodawca zmodyfikował nieco mechanizm zachęty finansowej dla powstałej na skutek połączenia nowej gminy ${ }^{10}$.

Ponadto warto zwrócić uwage na umieszone w tabeli 4 wybrane wskaźniki obciążeń dochodów budżetu miasta Poznania z tytułu obsługi zadłużenia i wydatków własnych. Dane obejmują cztery lata. Wynikający z nich dynamiczny wzrost obciążeń przekłada się na pogorszenie możliwości zaciagania nowych zobowiązań, przeznaczanych na przykład na finansowy wkład własny związany $z$ realizacją inwestycji dofinansowanych z funduszy europejskich przyznanych Polsce do 2020 roku. Stąd też można przypuszczać, iż zgłoszona przez Prezydenta Miasta Poznania propozycja połączenia z ościennymi gminami, i związany z nią finansowy bonus integracyjny, była motywowana nie tylko altruistycznymi przesłankami realizacji inwestycji infrastrukturalnych w integrujących się z Poznaniem gminach. Pozyskane środki bonusu integracyjnego byłyby potrzebne budżetowi miasta Poznania na poprawę wskaźników budżetowych i dofinansowanie kluczowej obietnicy wyborczej - budowy trasy tramwajowej do poznańskich Naramowic.

Tabela 4

Wskaźniki dla zobowiązań wg tytułów dłużnych dla Miasta Poznania

\begin{tabular}{||l|c|c|c|c|}
\hline & $\mathbf{2 0 1 1}$ & $\mathbf{2 0 1 2}$ & $\mathbf{2 0 1 3}$ & $\mathbf{2 0 1 4}$ \\
\hline Udział zobowiązań ogółem w dochodach ogółem & $71,8 \%$ & $67,3 \%$ & $69,4 \%$ & $57,8 \%$ \\
\hline $\begin{array}{l}\text { Obciążenie dochodów ogółem wydatkami na ob- } \\
\text { sługę zadłużenia }\end{array}$ & $9,4 \%$ & $9,6 \%$ & $15,1 \%$ & $9,6 \%$ \\
\hline $\begin{array}{l}\text { Obciążenia dochodów własnych wydatkami na ob- } \\
\text { sługę zadłużenia }\end{array}$ & $13,3 \%$ & $14,1 \%$ & $22,3 \%$ & $14,2 \%$ \\
\hline $\begin{array}{l}\text { Obciaż̇enie dochodów bieżących wydatkami bie- } \\
\text { żącymi i obsługą zadłużenia }\end{array}$ & $101,4 \%$ & $102,9 \%$ & $104,9 \%$ & b.d. \\
\hline
\end{tabular}

Źródło: Opracowanie własne na podstawie danych zamieszczonych w serwisie: http://www.mf.gov.pl.

10 Por. art. 41a, ustawa o dochodach samorzqdu terytorialnego. ,[...] dla gminy, której dochód z tytułu udziału w podatku dochodowym od osób fizycznych w przeliczeniu na jednego mieszkańca jest niższy od dochodu z tytułu udziału w podatku dochodowym od osób fizycznych dla wszystkich gmin w kraju w przeliczeniu na jednego mieszkańca, wskaźnik udziału we wpływach z podatku dochodowego od osób fizycznych, określony w art. 4 ust. 2, w okresie 5 lat, począwszy od dnia 1 stycznia roku następującego po roku, w którym podjęto decyzje o połączeniu, jest zwiększony o wskaźnik Zg”. 
Zasadniczy cel łączenia gmin był uzasadniany następującymi argumentami:

1) skorzystaniem $\mathrm{z}$ finansowego bonusu integracyjnego i podziałem kwoty dla zainteresowanych gmin;

2) rozbudową z Dębca do Lubonia sieci tramwajowej;

3) budową wiaduktu nad torami kolejowymi na granicy Poznania i Plewisk;

4) rozbudową wiaduktu w ciągu ul. Opolskiej łączącego Poznań z Luboniem;

5) wybudowaniem nowego budynku szkoły;

6) dofinansowaniem kluczowych dla nowopowstałej gminy inwestycji drogowych.

W dyskusjach na temat połączenia pominięto, lub nie przywiązano wystarczającej wagi do następujących kwestii:

1) konieczności uwzględnienia opinii rady powiatu poznańskiego;

2) uszczuplenia dochodów powiatu poznańskiego;

3) zasadniczego ograniczenia samorządności w przyłączonych gminach;

4) alternatywnych form współpracy i ich zacieśnienia - scenariusz intensyfikacji współpracy;

5) możliwej marginalizacji interesów mieszkańców przyłączonych gmin;

6) kosztów integracji m.in. administracyjnych i społecznych;

7) wówczas zawieszonych prac nad projektem ustawy o powiecie metropolitalnym (teraz o związkach metropolitalnych);

8) konieczności przeprowadzenia wyborów samorządowych w nowopowstałej gminie;

9) trudnej sytuacji budżetowej miasta Poznania, dla którego bonus integracyjny byłby istotnym zastrzykiem środków pozwalającym na zaciagniecie nowych zobowiązań i realizację projektów znajdujących się w programie wyborczym prezydenta Jacka Jaśkowiaka;

10) braku prawnie wiążącego kontraktu połączeniowego wyznaczającego kierunki działania nowych władz po połączeniu, co znacząco utrudnia wypracowanie politycznego i społecznego konsensusu wokół idei połączenia gmin;

11) konieczności określenia zasad obowiązywania aktów prawa miejscowego i zasad funkcjonowania jednostek i instytucji łączących się gmin po konsolidacji (Kudra, 2015); 
12) braku instrumentów wsparcia organizacyjnego i finansowego przed konsolidacją gmin - na wzór funduszy przedakcesyjnych, które są dostępne dla państw przystępujących do UE;

13) wystąpienia $z$ inicjatywą ustawodawczą w sprawie opracowania na wzór warszawskiej, tzw. ustawy poznańskiej;

14) formalnych kwestii gwarantujących realizację kontraktu integracyjnego po połączeniu gmin;

15) restrukturyzacji miejskich spółek, jednostek organizacyjnych lub zakładów budżetowych przyłączonych gmin;

16) innych kwestii jak np. zmiany systemu gospodarki odpadami komunalnymi.

Większość wójtów, burmistrzów ościennych gmin wraz ze Starostą powiatu poznańskiego negatywnie ustosunkowała się do takiego modelu integracji. Na wielu forach podkreślano, że mechanizm integracyjny, jak i związany z nim bonus finansowy, jest adresowany dla gmin małych, liczących poniżej 5 tysięcy mieszkańców, które ponadto nie współpracują ze sobą ściśle przy realizacji określonych zadań publicznych. Podkreślano jednocześnie, że Poznań, jak i gminy aglomeracji poznańskiej już dzisiaj bez korekty swych granic, efektywnie realizują określone usługi publiczne, racjonalizując przy tym wydatki budżetowe, tworząc dobre warunki do współegzystowania gmin obwarzankowych i miasta Poznania. Przywoływane przez Prezydenta Miasta Poznania przykłady integracyjne w Polsce - casus Rzeszowa i Zielonej Góry - zasadniczo różnią się od uwarunkowań forsowanego pomysłu. W kontekście Rzeszowa i Zielonej Góry mówimy o łączeniu się gminy wiejskiej z gminą miejską przy zastosowaniu w pierwszym przypadku tzw. taktyki salami, w drugim zaś poprzez skorzystanie pierwszy raz w historii z mechanizmu łączenia gmin i powstania nowej gminy. W jednym, jak i w drugim przypadku motywacją do integracji była chęć pozyskania przez gminy miejskie potrzebnych do ich rozwoju terenów inwestycyjnych, lepsze skomunikowanie z gminą wiejską, brak satysfakcjonujących form współpracy. Warto odnotować, że preferowanym scenariuszem jest łączenie gmin w całości zamiast, jak to ma miejsce w przypadku Rzeszowa, wydzielania z nich poszczególnych części.

Pomimo atrakcyjnie brzmiącego finansowego bonusu integracyjnego, władze podpoznańskich gmin, mając na względzie zapewnienie swoim mieszkańcom gwarantowanych nie w gentelmens agrément, lecz w egzekwowalnym akcie konsolidacyjnym, warunków decyzji o łączeniu gmin, nie podjęły dalszych prac nad propozycją Jacka Jaśkowiaka. 
Jak się wydaje styl rozpoczętej debaty konsolidacyjnej, jak i „niedoskonałości obecnie obowiązujących przepisów prawa stanowią niewątpliwie barierę dla upowszechnienia idei dobrowolnego połączenia gmin, którą wespół z oporem niektórych lokalnych polityków obawiających się bezpowrotnej utraty mandatu, trudno będzie przezwyciężyć li tylko zwiększeniem premii rządowej za dokonanie połączenia" (Kudra, 2015). Podnoszona w dalszej kolejności przez Prezydenta Miasta Poznania koncepcja wprowadzenia opłat za wjazd do centrum Poznania jako element polityki transportowej, zamknie miasto i utrudni jego komunikację z ościennymi gminami. Będzie bez wątpienia krokiem obniżającym zaufanie do Poznania i budującym antagonizmy społeczne łącznie przyczyniające się do fragmentacji aglomeracji poznańskiej. Ponadto stworzenie systemu transportu zbiorowego opartego na sieci kolejowej i tramwajowej wraz z dobrze zarządzaną przestrzenią parkingową może doprowadzić do ograniczenia poziomu kongestii transportowej. Tym samym inne działania, w tym stworzenie systemu opłat, nie będą konieczne (Bobrowska, Igliński, 2012, s. 20).

\section{Podsumowanie}

W przygotowanej przez zespół pracowników Ministerstwa Administracji i Cyfryzacji Zielonej Księdze dot. Obszarów Metropolitalnych wskazuje się dwa nurty reform metropolitalnych na świecie dotyczące sposobu organizacji struktur administracyjnych. Pierwszy - tradycyjny - model polega na wprowadzeniu jednolitej władzy ogólnometropolitalnej koncentrującej zadania metropolitalne w jednym ośrodku przy zachowaniu relacji hierarchicznych. Ośrodek ten posiada status albo podstawowej jednostki zasadniczego podziału terytorialnego kraju - gminy, albo powiatu. Drugi model - kooperacyjny - oparty jest na założeniach koncepcji metropolitan governance - metropolitalne współzarządzanie. Charakteryzuje się współpracą JST w ramach określonych struktur administracyjnych, którymi mogą być związki, zrzeszenia czy stowarzyszenia metropolitalne (Zielona Księga, 2012, s. 7).

Analiza obszarów i form współpracy gmin należących do poznańskiego MOF wskazuje, że ich włodarze dostrzegają korzyści z konsolidacji swoich polityk w określonych dziedzinach. Wśród nich wymienić należy realizację zadań w zakresie zbiorowego transportu publicznego, gospodarki odpadami komunalnymi, zbiorowego zaopatrzenia w wodę, odbiór ścieków komunalnych, promocję turystyki, promocję gospodarczą, prace koncepcyjne 
w zakresie zagospodarowania przestrzennego, realizację zadań związku ZIT i in. Dotychczasowe forum debaty metropolitalnej stanowi stowarzyszenie Metropolia Poznań. Zakresem swoich projektów obejmuje obszar całej aglomeracji poznańskiej. Określa 5 osi i 28 programów strategicznych, które komponują się z katalogiem kompetencji związków metropolitalnych.

Gminy Metropolii Poznań świadomie zdecydowały się na wybór scenariusza integracji zgodnego $\mathrm{z}$ założeniami metropolitan governance. Intensyfikacja współpracy w oparciu o związki międzygminne, związki gminno-powiatowe, centra usług wspólnych, związki metropolitalne ze względu na przedstawicielski charakter organów decyzyjnych daje gminom większy wpływy na podejmowane decyzje o znaczeniu strategicznym, jak i te określające standardy i koszty życia ich mieszkańców. Te argumenty mogą być decydujące dla tych włodarzy mniejszych gmin, którzy w obawie przed „efektem wymywania” przez duże miasto niechętnie patrzą na tego typu współpracę.

Propozycję o łączeniu ościennych gmin z miastem Poznaniem ze względu na niedoskonałość przepisów prawnych gwarantujących dotrzymanie warunków integracji, jak również z powodu dostępnych alternatywnych form współpracy i możliwość jej zacieśnienia, możliwej marginalizacji interesów mieszkańców przyłączonych gmin, należy ocenić jako nieadekwatną dla potrzeb rozwojowych aglomeracji poznańskiej. Być może w wyniku zacieśniania współpracy w formule związku metropolitalnego wszystkich gmin poznańskiego MOF będziemy mieli do czynienia z procesualnym scalaniem gmin. Na przeszkodzie powołania związku metropolitalnego może stanąć konstrukcja budżetu związku.

Kompetencje związków metropolitalnych pokrywają się z już dziś objętymi międzygminną współpracą usługami publicznymi. Tym samym powołanie związku metropolitalnego będzie wyrazem woli politycznej i kalkulacją skutków finansowych dla gmin. Formuła związku z punktu widzenia mniejszych gmin, ze względu na przedstawicielski charakter organów związku, stanowi alternatywę dla porozumień międzygminnych, czy też dla samodzielnej realizacji określonych usług.

Aglomeracja Poznańska ma przed sobą następujące scenariusze rozwoju:

1) scenariusz związku metropolitalnego - scenariusz transformacji;

2) scenariusz pogłębiania współpracy w aktualnych jej formatach lub z uwzględnieniem ich zmiany np. przekształcenia porozumień w formułę związku międzygminnego - scenariusz modyfikacji; 
3) zachowania dotychczasowego modelu kooperatywnej współpracy bez wprowadzania jakichkolwiek zmian - scenariusz zachowania statusu quo.

Testem na metropolitalne myślenie jest mechanizm zarządzania ZIT, który wymusza ujednolicenie polityk gmin w obszarze jego stosowania. Wspiera i premiuje konsorcja gminne powstałe celem realizacji wspólnych inwestycji o znaczeniu ponadgminnym. Współpraca międzygminna w MOF dzięki uzyskanym środkom zaliczanym do budżetu ZIT wkracza w nowy etap integracji aglomeracyjnej wymagającej decyzji politycznych, często jednomyślności, zawiązywania koalicji wokół określonych rozwiązań, lub też budowania pakietów decyzyjnych w części satysfakcjonujących każdego z ich autorów. ZIT wpisuje się w scenariusz transformacji i modyfikacji. Może stanowić kolejny etap w scenariuszu procesualnego scalania funkcji gmin i świadczenia przez nie na określonym poziomie, dotychczasowych lub nowych usług publicznych.

Scenariusz rozwoju aglomeracji poprzez łączenie gmin z miastem Poznaniem nie stanowi alternatywy dla scenariusza metropolitalnego. Związek metropolitalny, szanując tradycje samorządowe każdej z gmin, daje im wpływ na podejmowane decyzje, kreśli zasadniczo adekwatny do potrzeb metropolitalnych katalog kompetencji i stanowi kolejną formę pogłębiania integracji gminnej wokół zdefiniowanego w ustawie rdzenia integracji metropolitalnej.

\section{Bibliografia}

Akty prawne:

Krajowa Polityka Miejska przyjęta przez Radę Ministrów na posiedzeniu $w$ dniu 20 października 2015 roku, https://www.mr.gov.pl/strony/zadania/politykarozwoju-kraju/polityka-miejska/.

Koncepcja Przestrzennego Zagospodarowania Kraju.

Statystyczne Vademecum Samorzadowca 2015, Aglomeracja Poznańska, Urząd Statystyczny w Poznaniu, www.stat.gov.pl/bdl, 4.12.2015.

Strategia Rozwoju Aglomeracji Poznańskiej - Metropolia Poznań 2020 (2011), Konsorcjum Badań nad Aglomeracją Poznańską, Centrum Badań Metropolitalnych, Uniwersytet im. Adama Mickiewicza, Poznań.

Uchwała Rady Metropolii Poznań nr 3/2013 z dnia 18 kwietnia 2013 roku w sprawie petnienia zadań zwiazku ZIT.

Uchwała Rady Ministrów nr 239 z dnia 13.12.2012 r. w sprawie przyjęcia Koncepcji Przestrzennego Zagospodarowania Kraju do 2030 roku, Monitor Polski z dnia 27.04.2012, poz. 252. 
Ustawa z dnia 8 marca 1990 r. o samorzqdzie terytorialnym, Dz. U. $1990 \mathrm{Nr}$ 16, poz. 95.

Ustawa z dnia 9 października 2015 r. o zwiqzkach metropolitalnych, Dz. U. 2015, poz. 1890.

Zielona Księga dot. Obszarów Metropolitalnych (2012), dokument do konsultacji, Ministerstwo Administracji i Cyfryzacji, Warszawa.

\section{Opracowania zwarte:}

Bobrowska K., Igliński H. (2012), Koncepcja wprowadzenia opłat za wjazd do centrum Poznania. Zalety $i$ wady rozwiazania, w: Transport publiczny $w$ aglomeracji poznańskiej - propozycje usprawnień, red. M. Szymczak, Biblioteka Aglomeracji Poznańskiej, nr 19, Poznań.

Bródka S., Zmyślony P. (red.) (2012), Turystyka w aglomeracji poznańskiej, Biblioteka Aglomeracji Poznańskiej, nr 20, Centrum Badań Metropolitalnych UAM, Poznań.

Kiełbus M., Kostrzewska J. (2012), Zalety realizacji zadań w formie zwiazku międzygminnego, Kancelaria Ziemski \& Partners, 20.12.2012, www.wspolnota. pl, 20.11.2015.

Krasnowolski A. (2012), Gospodarka komunalna - polski model, Kancelaria Senatu, Biuro Analiz i Dokumentacji, http://www.senat.gov.pl/gfx/senat/pl/senatopracowania/42/plik/plik046.pdf, 15.12.2015.

Kudra A. (2015), Tekst o prawnych aspektach łaczeni gmin zamieszczony na portalu prawo dla samorzadu, http://prawodlasamorzadu.pl/2015.03.12-uwarunkowania-prawne-laczenia-gmin.html\&strona=2, 29.12.2015.

Mikuła Ł. (2012), Zarzadzanie publiczne w Poznaniu na tle metropolii krajowych, w: Pozycja konkurencyjna Poznania wśród metropolii krajowych i europejskich, red. T. Kaczmarek, Biblioteka Aglomeracji Poznańskiej, nr 22, Centrum Badań Metropolitalnych UAM, Poznań.

Szymczak M (red.). (2012), Transport publiczny w aglomeracji poznańskiej-propozycje usprawnień, Biblioteka Aglomeracji Poznańskiej, nr 19, Poznań.

Zmyślony P. (2012), Turystyka i rekreacja w aglomeracjach, w: S. Bródka, P. Zmyślony, Turystyka w aglomeracji poznańskiej, Biblioteka Aglomeracji Poznańskiej, nr 20, Centrum Badań Metropolitalnych UAM, Poznań.

\section{Directions of the development of the Poznań agglomeration - remarks on the current cooperation and proposals of including neighboring municipalities in the City of Poznań}

\section{Summary}

In many respects, the motivation of municipal integration activities does not change. In the context of the challenges posed by the agglomeration of Poznan and 
neighboring municipalities, a group of residents' common interests can be identified which call for a new, integration-related form of management to be implemented on account of functional connections. Misunderstanding of competition may lead to individual municipalities being excluded and marginalized in the region and the state. Consequently, the current benefits of cooperation will lose importance, which may translate into the fragmentation of the policy of the Poznan agglomeration. The metropolitan project for Poznań identifies the needs of the agglomeration, indicates the direction of activities in the field of public transportation, spatial management, security and sectoral cooperation. This project does not assume that different municipalities will be administratively merged, however, but is based on the principles of metropolitan governance. It refers to and implements a model of integration founded on common strategic goals that are feasible within the framework provided by national legislation and European models of the cooperation of local governments. Thanks to the new distribution mechanism of EU resources within regional policy, Integrated Territorial Investment (ITI), Poznań and the county of Poznań are encouraged to tighten cooperation. This integration spill-over may result in the emergence of a new model of metropolitan governance. A new kind of agglomeration-related cooperation executed above the level of municipalities calls for political action, frequently - for unanimity, establishing coalitions to promote certain solutions, or developing decision packages only partially satisfactory for their respective authors.

Key words: agglomeration, Poznań, integration, metropolitan governance 